\title{
AS PESSOAS E A ECONOMIA: ALGUMAS POSSIBILIDADES DESTE ENCONTRO
}

\author{
Por Andréa Leite Rodrigues
}

Professora da Escola de Administração de Empresas de São Paulo, Fundação Getulio Vargas - São Paulo - SP, Brasil

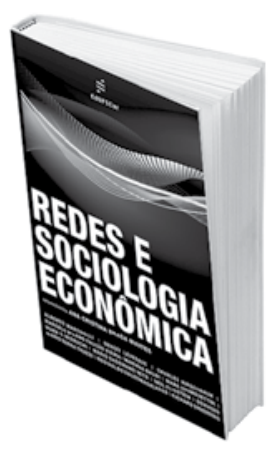

\section{REDES E SOCIOLOGIA ECONÔMICA}

De Ana Cristina Braga Martes (Org). São Carlos: EdUFSCar, 2009. 336 p.

A sociologia econômica (SE) é um campo em desenvolvimento. Trata-se de braço da sociologia que faz aberta crítica à noção de Homo economicus e à teoria da escolha racional. Surgiu como resposta às teorias da economia clássica e neoclássica, e enfatiza a ideia de que para entender o mercado é necessário conhecer a natureza das relações sociais nas quais ele está inserido. Nega, portanto, qualquer possibilidade de que os atores sociais só visem satisfação por meio de ação utilitária, pautada em interesses individuais. Preconiza que a experiência humana, mesmo nas relações de produção mercantis, não está isenta das influências da estrutura das relações sociais, do contexto social vigente e dos processos históricos que definiram a própria organização da produ- ção. Nos últimos anos, autores da SE passaram a dar importância também a fluxos de informação como processos de formação de redes, oferecendo grande contribuição aos estudos em Administração, particularmente à teoria das organizações.

A noção de que as organizações estejam imersas em redes sustenta outro campo de estudos que, tanto quanto a SE, está em pleno desenvolvimento. Tal abordagem reforça as críticas às premissas da teoria econômica neoclássica, pois as redes colocam em dúvida a ideia do indivíduo atomizado, modificando a unidade de análise para relações entre indivíduos ou entre organizações. Essa é a ideia de base para o entendimento da vida social por meio de sua arquitetura de relações, na qual a questão importante a responder é qual a posição que o indivíduo ocupa na teia de relacionamentos e, com base nisso, quais recursos mobiliza, acessa ou influencia.

Redes e sociologia econômica é obra organizada pela professora Ana Cristina Braga Martes, do Departamento de Gestão Pública da FGV-EAESP. Divide-se em duas partes, cada uma com contribuições distintas, mas complementares: a primeira destinase à apresentação de marcos teóricos seminais para o campo; a segunda, a artigos que contêm pesquisas empíricas desenvolvidas no Brasil. Oferece, portanto, uma boa gama de opções de leituras relevantes, com distintos enfoques, mas com significativa contribuição para o avanço do conhecimento. É uma boa opção tanto para versados como para iniciantes. Ao final da leitu- 
ra é possível construir um glossário de termos e um mapa bibliográfico com conceitos, ideias, debates e autores relevantes não apenas para a sociologia econômica, mas para as redes sociais também. A obra, portanto, cumpre a missão a que veio.

Para a área de Administração em especial, o livro é recurso interessante para reforçar a ideia de trabalhar com paradigmas alternativos, diferentes daqueles preconizados pela escola clássica, origem de todo o conhecimento em gestão e ainda tão presente nos conteúdos das diversas disciplinas dos cursos de graduação e pós. Dado o pragmatismo característico dos administradores, são bem-vindos recursos como este, que amparam abordagens baseadas em conceitos como instituição, embeddedness (imersão) e redes.

Entretanto, cabe um comentário, à guisa de sugestão, para futuros trabalhos com o mesmo perfil. A obra poderia conter, também, um capítulo de conclusão, conferindo mais espaço a esclarecimentos, discussões e interrelações entre capítulos. Indo além, dada a natureza complexa do tema, seria interessante que os capítulos teóricos da primeira parte viessem todos acompanhados de textos associados, com comentários de autores convidados, no estilo do Handbook de estudos organizacionais, em sua versão brasileira. Esse modo de organização muito auxilia na divulgação e disseminação da obra entre pesquisadores, professores e alunos, além de aumentar sensivelmente a capacidade de aprendizagem e familiarização com os temas, autores e obras.

O capítulo 1 do livro é a tradução do trabalho seminal de Mark Granovetter, considerado um marco no advento da nova sociologia econômica. Nele encontra-se o conceito de embeddedness, traduzido por "imersão", originalmente citado na obra $A$ grande transformação, do economista polonês Karl Polanyi. O texto desenvolve a discussão sobre preferências e racionalidade, opondo-se à escola clássica.

No capítulo 2, Neil Fligstein recupera o importante problema da ação na sociologia, outro tema clássico, já presente em Weber, Durkheim, entre outros. Segundo o autor, trata-se da habilidade de motivar atores à ação coletiva, o que é vital para a construção e reprodução da ordem social.

$\mathrm{O}$ conceito de desenvolvimento sustentável como forma de se repensar a economia é discutido por Benoît Lévesque no capítulo 3. O artigo é rico para situar o leitor na chamada nova sociologia econômica, pois compara a produção francesa com a americana.

Mark Mizruchi assina o capítulo 4 , que trata de redes sociais. A análise de redes tem origem na sociologia estruturalista, que parte do princípio de que fatores objetivos, mais do que subjetivos, são determinantes do comportamento humano. Assume-se que é a estrutura das relações sociais que determina seu próprio conteúdo. O capítulo oferece significativa contribuição para entender como a teoria institucional e a teoria das redes podem ser abordagens complementares para tratar o problema da ação socialmente imersa.

O capítulo 5, de Richard Swedberg, pode ser considerado o mais hermético de todo o livro. O autor esclarece ao final que fez uma tentativa para delinear uma agenda de pesquisa para uma sociologia econômica do capitalismo. A produção, a troca, o consumo e o lucro constituem os principais temas, acrescentando-se como fatores adicionais o direito, a política e a cultura. No centro das discussões, o papel dos interesses e a forma como atuam nas relações sociais.

O tema "empreendedorismo" é tratado no capítulo 6 por Alberto
Martinelli. Novamente um tema atual e relevante no universo das escolas de administração. Chama a atenção para a importância e os benefícios de se analisar o contexto sociocultural e político-institucional no qual surge e se desenvolve o empreendedor.

Na sequência, a obra apresenta quatro artigos com pesquisas empíricas que têm por arcabouço teórico a sociologia econômica e as redes sociais.

Os capítulos 7 e 9 versam sobre redes sociais. Ambos oferecem contribuições para aprender sobre imersão, posição, arquitetura e conteúdo da rede no sentido de estimular o comportamento tanto dos indivíduos como das organizações.

O conceito "habilidades sociais" é abordado por Magalhães no capítulo 8 para analisar cooperativas do mercado de leite. Além de bom diálogo com o capítulo assinado por Fligstein, este trabalho traz ao debate a questão do capital social como recurso tão ou mais importante que o capital monetário.

A obra encerra-se com o artigo de Charles Kirschbaum sobre o nascimento da indústria de filmes no Brasil. $O$ autor utiliza a análise de redes para compreender a dinâmica em campos organizacionais e constrói um trabalho robusto com método quantitativo. É o único artigo em todo o livro que oferece item especial com direções para pesquisa futura. Sendo um dos objetivos da obra disseminar conhecimento, suscitar interesse e angariar a simpatia de pesquisadores, teria sido interessante ter mais espaços como este ao longo do livro, talvez em capítulo adicional, não só à guisa de encerramento e conclusão, mas oferecendo ao leitor uma proposta de agenda de pesquisa ou mesmo um breve elenco de possibilidades sobre temas, autores e discussões relevantes para o futuro dos estudos sobre redes sociais e sociologia econômica no Brasil. 